\title{
Safety of H1N1 and seasonal influenza vaccines in egg allergic patients in British Columbia
}

\author{
Sara H Leo*, John Dean, Edmond S Chan \\ From Canadian Society of Allergy and Clinical Immunology Annual Scientific Meeting 2010 \\ Victoria, Canada. 3-6 November 2010
}

\section{Background}

The publicity of the H1N1 pandemic increased the demand for flu vaccination including in the egg allergic. The MMR protocol is safe but cumbersome. A simpler but less tried protocol with vaccines having $<1.2 \mu \mathrm{g} / \mathrm{ml}$ egg protein has been available [1]. As current Canadian seasonal and $\mathrm{H} 1 \mathrm{~N} 1$ vaccines fulfill this criterion, we hypothesized either split or full administration is safe without skin testing.

\section{Materials and methods}

Egg allergic individuals were administered the H1N1 $(\mathrm{n}=50)$ and/or the seasonal influenza $(\mathrm{n}=31)$ vaccines in fall 2009. Twenty-one patients received skin prick and intradermal testing to vaccine prior to administration. Individuals with negative skin tests or those able to eat hidden egg received the full vaccine as a single shot. Those with positive skin tests or those unable to eat hidden egg were given the vaccines in a split dose $(10 \%$ of total dose, followed by $90 \%$ if no reaction after 30 minutes). Patients were observed for one hour.

\section{Results}

No positive skin tests or allergic reactions were seen in the patients receiving the $H 1 N 1$ vaccine $(n=50)$. Three patients had a positive intradermal test to the seasonal influenza vaccine but no immunization reaction. Three patients $(9.7 \%)$ had transient local reactions to the seasonal influenza vaccine.

\section{Conclusions}

No significant reactions were seen in egg-allergic individuals receiving the $\mathrm{H} 1 \mathrm{~N} 1$ or seasonal influenza vaccines

\footnotetext{
* Correspondence: sleo@cw.bc.ca

Department of Pediatrics, Division of Allergy, University of British Columbia,

BC Children's Hospital, Vancouver, British Columbia, Canada, V6H 3V4

Full list of author information is available at the end of the article
}

for a total of eighty-one vaccinations. Positive skin tests for the seasonal influenza vaccine were not predictive of subsequent allergic reaction.

Published: 4 November 2010

\section{Reference}

1. James JM, Zeiger RS, Lester MR, et al: Safe administration of influenza vaccine to patients with egg allergy. J Pediatr 2006, 133:624-628.

doi:10.1186/1710-1492-6-S2-P4

Cite this article as: Leo et al:: Safety of H1N1 and seasonal influenza vaccines in egg allergic patients in British Columbia. Allergy, Asthma \& Clinical Immunology 2010 6(Suppl 2):P4.

Submit your next manuscript to BioMed Central and take full advantage of:

- Convenient online submission

- Thorough peer review

- No space constraints or color figure charges

- Immediate publication on acceptance

- Inclusion in PubMed, CAS, Scopus and Google Scholar

- Research which is freely available for redistribution 